\title{
THE SPANISH EXPULSION AND THE. PORTUGUESE PERSECUTION THROUGH THE EYES OF THE HISTORIAN R. GEDALYA IBN YAHYA *
}

ABRAHAM DAVID

The Hebrew University of Jerusalem

The closing period of the Middle Ages, from the Spanish Expulsion until the late sixteenth century, saw the appearance of Jewish historiographical compositions of varied length and quality. The majority were written by Iberian exiles or their descendants. Noteworthy works in this genre include: ספר יוחסין (Book of Genealogy), written by the well-known Spanish astronomer Abraham Zacuto '; (Book of Tradition) written by Abraham ben Solomon of Torrutiel 2; שבט יהודה (The Scepter of Judah), written by Solomon Ibn Verga ${ }^{3}$; Consolaçam as Tribulaçoens de Israel (Consolation for the Tribulations of Israel), written by the ex-converso Samuel Usque 4; דברי הימים למלכי צרפת ובית אוטומאן התוגר (History of the Kings of France and Turkey), written by Joseph ha-Kohen of Genoa 5; and שלשלת הקבלה (Chain of Tradition), written by Gedalya Ibn Yahya, the subject of the present paper.

\footnotetext{
* This article is based on a lecture I presented in a conference: «1492 - Expulsion des Juifs d'Espagne" (Université de Paris-Sorbonne [Paris IV], May 1992). It has been translated from the Hebrew by Mrs. Dena Ordan.

${ }^{1}$ H. Filipowsky (ed.), with an introduction by A. H. Freimann, Jerusalem 1963.

2 A. E. Harkavy (ed.), appended to the Hebrew version of H. Graetz, דברי ימי ישראל, trans. S. P. RABINOwITZ, Warsaw 1898, vol. 6. Recently published by A. DAvid (ed.), Two Chronicles from the Generation of the Spanish Exile [in Hebrew], Jerusalem 1979, pp. 21-41.

3 A. Shohat (ed.), with an introduction by Y. BAER, Jerusalem 1947.

4 The work contains three dialogues. The first edition, in Portuguese, was published at Ferrara in 1553. English translation by M. A. COHEN, Consolation for the Tribulations of Israel, Philadelphia 1965. An annotated edition of the third dialogue was published by G. I. GelbarT, A Consolation for the Tribulations of Israel, Third Dialogue, New York 1964.

${ }^{5}$ The work contains three parts. Parts I-II (Sabbioneta 1554); part III: D. A. Gross (ed.), Jerusalem 1955. A separate collection of Jewish material by ha-Kohen,
} 
The blossoming of Jewish historiography in the sixteenth century was directly connected to the tragic events affecting Iberian Jewry in the late fifteenth century. Sixteenth century Jewish historiography was characterized by the effects of crises on the one hand, and by intellectual openness on the other. Jewish historiography naturally aspired to find a fitting explanation for the question of Jewish existence in the Diaspora in light of the Jewish people's distress throughout the ages, an enigma intensified by the terrible catastrophe which struck Iberian Jewry at the turn of the fifteenth century.

The extent to which we observe the past is reinforced in no small measure by political, social, and cultural considerations. Forces operating in the latter half of the fifteenth century brought severe crises to European Christian society. Among these we must cite the prevailing power of Christianity's foes (as evidenced by the Ottoman conquest of Constantinople in 1453), and the internal disintegration which eventually gave birth to the Reformation. In addition, the historiographical awakening in humanistic Renaissance circles strongly influenced the Jews. It was no accident that Italy served as an historical observation point, since this country saw both the arrival and absorption of Jewish exiles from Spain and Portugal, as well as being the main conduit for Renaissance culture. Similarly, it is not surprising that the majority of sixteenth century Jewish chroniclers came from the ranks of Spanish and Portuguese emigrants and their descendants ${ }^{6}$.

titled עמק הבכא, was published separately. For a critical edition, see K. AlmbladH (ed.), Sefer Emeq ha-Bakha, Uppsala 1981.

${ }^{6}$ For recent studies of Jewish historiography following the Spanish Expulsion see H. H. Ben-SAsson, «On Trends and Problems in Medieval Jewish Chronography» [in Hebrew], in S. EtTinger et al. (eds.), Historians and Historical Schools [in Hebrew], Jerusalem 1962, pp. 32-34; Y. H. Yerushalmi, «Clio and the Jews: Reflections on Jewish Historiography in the Sixteenth Century", Proceedings of the American Academy for Jewish Research 46-47 (1979-1980) 607-638; IDEM, «Messianic Impulses in Joseph ha-Kohen", in B. D. CoOperman (ed.), Jewish Thought in the Sixteenth Century, Cambridge (Mass.) 1983, 460-487; IDEM, Zakhor, Seattle - London 1982, pp. 53-75; IDEM, «A Jewish Classic in the Portugues Language», Introduction to the reprint edition of Samuel Usque, Consalaçam as Tribulaçoens de Israel, Ferrara 1553, Lisbon 1989, pp. 15-112; R. BonfIL, «The Historian's Perception of the Jews in the Italian Renaissance: Towards a Reappraisal», REJ 143 (1984) 59-82; IDEM, «Riflessioni sulla storiografia ebraica in Italia nel cinquecento", Italia Judaica 2 (1986) 55-66; IDEM, «How Golden was the Age of the Renaissance in Jewish Historiography?», History and Theory 27 (1988) 78-102. 
Gedalya Ibn Yahya, the last chronicler mentioned above, the author of Šalšelet ha-kabbalâ, was the scion of a distinguished Portuguese Jewish family, many of whose sons had served in the courts of the kings and rulers of Spain and Portugal for generations. Gedalya's grandfather, David ben Joseph Ibn Yahya, arrived in Italy with his family circa 1497, at a time of forced mass conversions of Jews in Portugal ?. Born at Imola in northern Italy in 1526, Gedalya spent his childhood there; however, for the remainder of his life he wandered about the various towns of northern Italy. From his writings and erudition, it appears that he studied with important Italian Jewish sages. Gedalya, a moneychanger by profession, lost considerable capital when forced to leave the Papal States close to the 1569 expulsion decree. He spent his final years in the city of Alessandria in the Piedmont region, where he served in the rabbinate until his death in $1587^{\circ}$.

Of Gedalya's variegated literary work, pertaining mainly to the fields of homiletics, morality, and historiography, only a very small portion is still extant 9 . His writings clearly reflect his spiritual personality, and are outstanding for their integration of authentic Jewish tradition with Italo-Jewish humanism. Although Gedalya composed more than twenty works, only four have survived in printed and/or manuscript form. One known extant work is inaccessible.

The writing of the historiographical treatise Šalšelet ha-kabbalâ (or ספר יחיא as Gedalya referred to it) lasted several decades. Begun in 1549 , it was concluded close to Gedalya's death in $1587^{10}$. This

7 On R. David Ibn Yahya's life in Italy, see A. MARX, "Glimpses of the Life of an Italian Rabbi", HUCA 1 (1924) 605-624; A. DAVID, "The Letters of Joseph haKohen» [in Hebrew], Italia 5 (1985) 15-17, 57-61.

${ }^{8}$ I devoted my doctoral dissertation, A. DAVID, The Historiographical Work of Gedalya Ibn Yahya author of «Shalshelet ha-Kabbalah" [in Hebrew], Jerusalem 1976 [Hereafter, A. DAvid, R. Gedalya Ibn Yahya]. For his biography, see ibid., pp. 4-16, 256-268; IDEM, "Gedalya Ibn Yahya, auteur de Shalshelet ha-Kabbalah», REJ 153 (1994) 101-132.

9 On Gedalya's variegated literary work, see A. DAvid, R. Gedalyah Ibn Yahya, pp. 17-22, 269-272; IDEM, "Gedalya Ibn Yahya", 125-132.

${ }^{10}$ On his historiographical treatise, see A. DAvID, R. Gedalya Ibn Yahya; IDEM, «R. Gedalya Ibn Yahya's Shalshelet Hakabbalah (Chain of Tradition): A Chapter in Medieval Jewish Historiography", Immanuel 12 (1981) 60-76. On some aspects of general history in Šalšelet ha-kabbalâ, see A. DAVID, "General History in the Book Shalshelet ha-Kabbalah» [in Hebrew], Koroth 9 (1986) 18-32. 
work is extant in two versions: a printed edition, of which there are more than fifteen known editions, and a manuscript version. Gedalya's demise shortly preceded the publication of the first edition (Venice 1587). A manuscript of Šalšelet ha-kabbalâ with the author's glosses between the rows and in the margins is extant in the Russian State Library in Moscow ${ }^{11}$. Probably copied in the late 1560 s, this manuscript version differs substantially from the printed edition ${ }^{12}$.

In his preface to the printed edition of Šalšelet ha-kabbalâ, Gedalya stated his intentions as follows:

I chose to divide this work into three parts: the first part being the chain of Jewish tradition from Adam until the present; the second being to inform you of some of the principles concerning celestial bodies and the heavenly world, the formation of the embryo and its development, and about magic - all this with great brevity ... and about coins and measurements in the Mishnah; the third being the chain of Gentile sages, and the persecutions of Israel, and the noteworthy innovations in each generation ${ }^{13}$.

Gedalya devoted the second section of the third part of Šalselet $h a-k a b b a l a ̂$ to a special discussion, showing through brief, continual description, the oppression, persecution, edicts, and disturbances that were a way of life for diaspora Jewish communities in medieval Europe. In this context, Gedalya attempts to provide an answer to the question of Jewish existence in the Diaspora. This problem engaged the attention of other first and second generation historians following the destruction of the Jewish community in the Iberian peninsula, including Abraham Zacuto, Solomon Ibn Verga, Samuel Usque, and Joseph ha-Kohen ${ }^{14}$, who often added tales of persecution to their chronicles in order to express their intense anger, or used expressions of anguish to show their hatred for Christianity, in whose name such wanton acts were committed. Others hoped

\footnotetext{
11 Ginzburg collection no. 652.

12 I am preparing a critical edition of Šalšelet ha-kabbalâ based upon this manuscript, to be published by the Ben-Zion Dinur, Center for Research in Jewish History. References or quotations from the printed edition (Venice 1587) will be cited as: P.; references or quotations from the abovementioned manuscript will be indicated as MS.

13 Šalšelet ha-kabbalâ, P. 4v.

14 See nos. 3, 4, 5.
} 
through their account to instill in their readers the spirit of Jewish martyrs throughout the ages.

Šalšelet ha-kabbalâ is an important source of information concerning the decisive events affecting the Jewish communities of Spain and Portugal in the last decade of the fifteenth century, especially the forcible mass conversions and the final destruction. For his information regarding the disturbances, Gedalya relied to some extent on other sources, of which only a small portion have been identified. Concerning several events occuring in Spain and Portugal, Gedalya preserved family traditions transmitted by relatives who had previously held high positions at the royal court. By presenting a brief survey of highlights from Šalšelet ha-kabbalâ, I intend to illustrate Gedalya's historiographical methods as well as to pinpoint his unique contribution to the documentation of this crucial historical period.

Gedalya very tersely describes the founding of the Spanish Royal Inquisition - established in 1481 at Seville. Any conversos suspected of observing Jewish customs or maintaining ties with their forefathers' faith were charged and investigated by the Inquisition, whose jurisdiction was immediately extended over all of Spain ${ }^{15}$. Gedalya adds that, during this period, one third of the Spanish Jewish population was baptized to Christianity ${ }^{16}$.

Gedalya also summarizes aspects of the 1492 Expulsion, very briefly recapping the Expulsion Act issued following the Christian conquest of Granada in that year ${ }^{17}$. On this point Gedalya contributes nothing new, with the exception of his numerical estimate of the exiles, who in his opinion numbered approximately six hundred thousand ${ }^{18}$. Although found in other sources ${ }^{19}$, this number is

15 On the Spanish Inquisition prior to the Expulsion, see H. BEINART, Conversos on Trial, Jerusalem 1981; IDEM, «La Inquisición Española y la expulsión de los judíos de Andalucía», in J. KAPLAN (ed.), Jews and Conversos, Jerusalem 1985, 103-123; IDEM, «The Expulsion from Spain: Causes and Results», in H. BEINART (ed.), Moreshet Sepharad: The Sephardi Legacy, Jerusalem 1992, vol. II, 11-24.

16 P. 115v. This information has been confirmed in a paper by Prof. H. Beinart, who has devoted many years to the study of the Spanish conversos. See H. BEINART, "The Records of the Inquisition - A Source of Jewish and Converso History", Proceedings of the Israel Academy of Sciences and Humanities 2 (1967) 211-227.

17 P. 112r, 113r-114r, 115r-116v; MS. 207v-208v.

18 P. $115 \mathrm{v}$; MS. 207v.

19 See A. David, R. Gedalya Ibn Yahya, pp. 100-101. 
undoubtedly an exaggeration. Don Isaac Abrabanel - a prominent Jewish spiritual figure in Spain at that time ${ }^{20}$ - cites three hundred thousand Jewish exiles ${ }^{21}$. The actual number of exiles is unclear. Demographically based evaluations by serious scholars range from approximately one hundred and seventy thousand exiles, to one hundred and twenty thousand, or even much less ${ }^{22}$. On this basis, we are justified in concluding that any demographic evaluation of the number of Spanish exiles is pure speculation.

Gedalya recounts that following the expulsion edict, issued on March 31, 1492, the authorities made determined efforts to avoid deporting those Jewish notables who held high positions in the monarchic administration and economy, especially courtiers, moneylenders, and tax farmers, by applying extreme pressure upon them to convert to Christianity, since authentic Jews were forbidden to remain in Spain from the end of July of that year. By these acts the rulers hoped to prevent significant economic damage to the Spanish crown:

Even though they [the Spanish authorities] exiled the Jews, they closed their borders [to prevent their emigration] so that the kingdom would not remain empty. Because many of the Jews were rich and clever, they were forced to convert. Many met their death as martyrs ${ }^{23}$.

We know from other sources of Jews who succumbed to this pressure, and converted to Christianity, like R. Abraham Seneor and his son-in-law, R. Meir Melamed ${ }^{24}$. The former held a rabbinical

20 There are many studies of various aspects of his personality. See, for example, B. Netanyahu, Don Isaac Abravanel: Statesman and Philosopher, Philadelphia 1972.

${ }^{21}$ See Abrabanel's preface to his commentary on Isaiah 46:3; the preface to his commentary on Kings; his book מעיני הישועה, Ferrara 1551.

22 See Y. BAER, A History of the Jews in Christian Spain, Philadelphia 1966, vol. 2, pp. 438, 510-511. See also H. BEINART, «The Expulsion», pp. 36-37; R. BonfIL, «The History of the Spanish and Portuguese Jews in Italy», in H. BEInART (ed.), Moreshet Sepharad, Jerusalem 1992, vol. II, pp. 217.

${ }^{23}$ P. 116r. On this issue, see Y. BAER, A History, vol. 2, pp. 436-437, 509-510; A. DAvid, "An Unknown Elegy on the Spanish Expulsion" [in Hebrew], Peamim 49 (1991) 24-31. On the Spanish Expulsion see the recent and comprehensive research of H. BEINART, The Expulsion of the Jews from Spain [in Hebrew], Jerusalem 1994.

${ }^{24}$ See Y. BAER, A History, Index; J. HACKer, "New Chronicles on the Expulsion of the Jews from Spain, Its causes and Results", [in Hebrew], Zion 44 (1980) 217-218, 222, 228; C. Carrete Parrondo, «R. Abraham Seneor (Fernán Pérez Coronel). 
post as well as being chief tax farmer in Castile. In contrast, the prominent Jewish philosopher, Don Isaac Abrabanel, who was the kingdom's treasurer on the eve of the Expulsion, refused to undergo baptism ${ }^{25}$. Abrabanel threw his lot in with the exiles, eventually finding his way to Naples, Italy ${ }^{26}$.

Gedalya proceeds one step further, piecing together stories from written Jewish sources and from oral traditions on the hardships suffered by the Spanish exiles in their search for a haven in Europe, North Africa, and the Orient. Many did not survive these hardships, and perished in the course of their wanderings by land and sea, suffering violence, poverty, homelessness, and hunger ${ }^{27}$. He informs us as well, that half of the exiles, some three hundred thousand, entered neighboring Portugal ${ }^{28}$. As mentioned above, this number is certainly exaggerated ${ }^{29}$.

Gedalya describes how the king of Portugal, John II, allowed the Spanish exiles to enter his country upon payment of a special head tax. However, Gedalya reports that shortly after the exiles' arrival in Portugal, this monarch's attitude underwent a radical change. Since not all of the Spanish exiles could pay the tax, he began to persecute them ${ }^{30}$. Gedalya also hints at the king's most extreme deed - the kidnapping and deportation of young Jewish

Conjeturas tradicionales y realidad documental», Sefarad 46 (1986) 111-121; E. GuTwirth, "Abraham Seneor: Social Tensions and the Court-Jew", Michael 11 (1989) 169-229; H. BeInART, «The Expulsion» pp. 34-36; IDEM, The Expulsion, pp. 385-466.

25 See Y. BAer, A History, vol. 2, pp. 437, 510; B. Netanyahu, Don Isaac Abravanel, pp. 59-60; H. BEINART, The Expulsion, pp. 467-480.

26 See B. Netanyahu, Don Isaac Abravanel, pp. 61-71.

27 See n. 17 above.

28 MS. 208v; P. 115v.

29 R. Abraham Zacuto notes in his ספר יוחסין, fol. 227r, that one hundred and twenty thousand Jews crossed the border into Portugal. This information is found in another contemporary source. See Y. BAER, A History, vol. 2, pp. 510-511; H. BEINART, «The Expulsion» pp. 36-37; IDEM, The Expulsion, pp. 269-272.

${ }^{30}$ For the persecutions of the Jews in Portugal during the reign of King John II, see M. Kayserling, Geschichte der Juden in Portugal, Leipzig 1867, pp. 108-119; A. David, R. Gedalya Ibn Yahya, pp. 109-111; M. J. Pimenta Ferro Tavares, Os Judeus em Portugal no seculo XV, Lisbon 1982, pp. 252-257; A. Gross, "On the Ashkenazi Syndrome of Jewish Martyrdom in Portugal in 1497" [in Hebrew], Tarbiz 64 (1994) 83-114. 
children to São Thomé, a desolate island in western Africa ${ }^{31}$. In his words:

The king cleverly inquired whether all the [Spanish] exiles had paid their taxes according to their status. Upon discovering that many had not paid, he was filled with rage, and he took their sons as security. The children, aged three to ten, were exiled to a parched and desolate island named São Tome, which was uninhabited because of the אלגרדי ${ }^{32}$, which are deadly poisonous snakes. Most died from snakebite, while others starved to death. Only a small number were rescued ${ }^{33}$.

This terrible episode of child deportation to São Thomé Island is well documented in both Jewish and Portuguese sources ${ }^{34}$.

I would like to direct special attention to two stories found in Šalšelet ha-kabbalâ which reflect the hostile attitute of the autochthonic Jews in Portugal, and in Rome as well, towards the Spanish exiles immediately following the Expulsion. The first story deals with Gedalya's great-grandfather, R. Joseph Ibn Yahya, a leading figure in the Lisbon Jewish community whose attempts to persuade the local Jews to welcome and to grant assistance to the Spanish exiles who had crossed the border into Portugal met with harsh resistance. Upon realizing that he was powerless, R. Joseph Ibn Yahya left Portugal, and relocated in Italy ${ }^{35}$. As Gedalya recounts:

31 This event will be discussed later.

32 In Portuguese, lagartos means 'alligators'. R. Gedalya mistakenly interpreted lagartos as 'snakes', even though the original source (see n. 34) stated: «alligators, serpents and other very venomous vermin" (G. I. GELBART edition).

${ }^{33}$ MS. 208v; P. 115v-116r.

34 There are several descriptions of this event in Jewish sources. The most detailed, which was R. Gedalya's source, is found in Samuel Usque, Consolaçam as Tribulaçoens de Israel, chaps. 26-27. See also the English edition by G. I. Gelbart, A Consolation, pp. 334-346, 351-354. On the other Hebrew sources reflecting this issue, see A. DAvid, R. Gedalya Ibn Yahya, pp. 109-111, 317-318; I. TishBy, Messianism in the time of the Expulsion from Spain and Portugal [in Hebrew] Jerusalem 1985, pp. 24-25, 41. The Portuguese sources are mentioned by M. KAYSERLING, Geschichte, p. 115; M. J. Pimenta Ferro Tavares, Os Judeus, pp. 256-257, 272.

35 We have some biographical data regarding R. Joseph Ibn Yahya. He was born in Lisbon in 1428, left Portugal in 1493 or the beginning of 1494, and died in Ferrara in 1498. See A. DAvid, R. Gedalya Ibn Yahya, pp. 112-113, 320-323. 
Know that those God-fearing Jews willing to go into exile to Portugal numbered $300,000{ }^{36}$. The majority of these exiles were poor, and Portugal could not readily contain all these Jews. The heads of the Jewish communities in the kingdom of Portugal took counsel to decide how to deal with the large number of Spanish exiles. They decided to strenuously attempt to prevent the exiles from entering Portugal so as not to make themselves loathsome in the eyes of the king, the courtiers, or the inhabitants. My greatgrandfather of blessed memory, the notable Don Joseph Ibn Yahya, objected to this great wrong in God's eyes, saying it was an act of scorn and provocation to close the gates of salvation to their brethren. He suggested that at the very least, they donate half their property to feed these souls, and rent boats to transport them from Portugal to Fez and other kingdoms. The [Portuguese] Jews refused to listen to the abovementioned notable. As a result, the exiles were forced to negotiate with the king of Portugal for entry; making an agreement as well that if required to leave, they would pay for boats he would provide. For the present, they had to pay a levy of two ducats per person. Some time later, due to an outbreak of pestilence in the city, the exiles wished to depart, and approached the king with a request for boats... When my great-grandfather, the notable, saw that his brethren rejected his advice, arbitrarily following the willfulness of their hearts in closing the gates of salvation to their exiled Spanish brethren, he elected to flee from that kingdom with his sons. In [5]253 [1493], he went to Italy ${ }^{37}$.

The second story regards the appearance of Spanish refugees at the gates of Rome. The Roman Jews responded by petitioning Pope Alexander VI to bar their entry into the Papal State. Not only did this pope reject their proposal, furthermore, he decreed that the Roman Jews be deported, and Spanish exiles allowed to settle in their stead. The Roman Jews were forced to pay a substantial sum in order to cancel the papal edict, as Gedalya relates:

I heard that the Roman Jews approached the pope with an offer of 1000 gold crowns to bar Spanish Jews from entering Rome. This was due to their fear of making themselves loathsome in the eyes of the town's noble courtiers. This angered the pope, and he asked them how they could treat their brethren so cruelly. He decreed that

${ }^{36}$ On the number of Spanish exiles who entered Portugal, see above p. 50.

${ }^{37}$ MS. 208v-209r; P. 115v-116r. 
the local Jews be exiled instead. As a result, the local [Jews] had to spend large sums in order to annul this decree, and some Spanish Jews entered Rome ${ }^{38}$.

A very similar story is found in Solomon Ibn Verga's שבט יהודה ${ }^{39}$. I believe, that although Gedalya was familiar with this historiographical treatise, occasionally relying on it in the composition of Šalšelet ha-kabbalâ, he did not copy this story directly from Ibn Verga's work.

Although these two stories about the Portuguese and Roman Jewish communities may contain legendary elements, both at least partially reflect reality. In my opinion, their main significance lies in their portrayal of the objections made by autochtonic Jews against integrating the newcomers. Apparently, the local Jews feared competition for their positions, jobs, or businesses. Moreover, the local Jews were unable to finance even a temporary stay for the exiles ${ }^{40}$. Recently, I found some Hebrew sources which indicate that a similar situation existed in Italy three generations later, in 1569, when Italian Jews were expelled from the Papal States. These exiles were also unable to receive adequate assistance from the Jewish communities outside the Papal States for even a brief period ${ }^{41}$.

On the other side of the coin, there is no doubt that philanthropic activities were undertaken for the Spanish exiles who arrived in Italy after the Expulsion. Gedalya mentions the Jewish philanthropist R. Yehiel Da-Pisa, a scion of the famous, wealthy Da-Pisa banking family, whose branches were situated in various Italian towns during the Renaissance period ${ }^{42}$. According to Gedalya, R. Yehiel attempted to provide support for the Spanish refugees who came to Italy after the Expulsion.

\footnotetext{
${ }^{38}$ MS. 209v; P. 116r.

39 A. ShOAт (ed.), chap. 57, pp. 123-124.

${ }^{40}$ See David, R. Gedalya Ibn Yahya, pp. 105-106, 111-112. On the second story, see BoNFIL, «The History», pp. 218-220.

${ }^{41}$ See A. David, «New Documents on the Church State Exiles in 1569 and Prior Edicts", [in Hebrew] Italia 10 (1993) 17-36.

${ }^{42}$ On this family, see D. KaufMann, "La famille 'de Pise'», REJ 31 (1895) 62-73; IDEM, "La famille de Yehiel de Pise», REJ 26 (1893) 83-110, 220-239; U. CASSUTO, "Sulla famiglia da Pisa", Rivista Israelitica 5 (1908) 227-238; 6 (1909) 1-30, 102-113, 160-170, 223-232; 7 (1910) 9-16, 72-86, 146-150; IDEM, Gli ebrei a Firenze, Florence 1918, Index.
} 
I heard from the community elders that in 1492, the year of the Spanish Expulsion, when many Jews fled Spain for Italy on their way to Turkey, that R. Yehiel Da-Pisa, of Pisa which is in Tuscany on the Mediterranean Sea, welcomed both rich and poor, feeding and accompanying them ... and provisioning all their needs ${ }^{43}$.

Here Gedalya mistakenly mentions R. Yehiel Da-Pisa, who died prior to the Expulsion, in $1490{ }^{44}$. On the other hand, we know from Jewish documents that his son Isaac Da-Pisa, who resided in Florence, actively provided financial support for Spanish exiles dwelling in Italy ${ }^{45}$. Undoubtedly, he is the person to whom Gedalya is referring.

In his brief description of the persecution of the Jews in Portugal during Emanuel I's reign (1495-1521), Gedalya relies on Samuel Usque's historiographical treatise -Consolaçam as Tribulaçoens de Israel ${ }^{46}$. Initially quite tolerant of the Jews, even cancelling his predecessor's brutal edicts, at the end of 1496, having contracted a marriage with the daughter of the Spanish monarchs Ferdinand and Isabella, Emanuel's attitude underwent a radical change. One of the nuptial conditions was the total expulsion of the Portuguese Jews. On December 24, 1496, the king issued an edict requiring the Jews to convert to Christianity, or leave Portugal within eleven months. Upon realizing that most Jews preferred to leave the country and that only a minority would accept Christianity, Emanuel decided to close the borders to prevent their mass flight. Moreover, he assembled all the Portuguese Jews in the royal court in Lisbon, where he forcibly baptized them ${ }^{47}$. Gedalya adds his own explanation for this monarch's change of heart, attributing it to Emanuel's realization that the exodus of the Jews would cause grave economic harm to his kingdom, as the Jewish population included many wealthy Jews

\footnotetext{
${ }^{43}$ MS. 132r; P. 65v.

44 See S. D. LuzzatTo, «Bibliothèque du feu Joseph Almanzi», Hebraeische Bibliographie 5 (1862) 146-147.

45 See J. HACKER, «Some Letters on the Expulsion of the Jews from Spain and Sicily" [in Hebrew], in E. ETHES - Y. SALmon (eds.), Studies in the History of Jewisih Society... Presented to Professor Jacob Katz [in Hebrew], Jerusalem 1980, 64-95.

${ }^{46}$ Usque, chap. 28; G. I. Gelbart, A Consolation, pp. 357-364. M. J. Pimenta Ferro Tavares, Os Judeus, pp. 483-510; I. Tishby, Messianism, pp. 24 ff.

47 On these events, see M. Kayserling, Geschichte, pp. 125-139; M. J. Pimenta Ferro Tavares, Os Judeus, pp. 483-510; I. Tishby, Messianism, pp. 24 ff., 48. MS. 209r; P. 116r.
} 
who were intimately involved in the economic development of Portugal:

When the king heard of their intention to depart, he feared that the kingdom would remain like an empty fishing net, for the Jews were extremely numerous, and they possessed most of the kingdom's wealth ${ }^{48}$.

This point of view is confirmed by a Portuguese source, which mentions that the Portuguese secretary of state warned King Emanuel I in a special memorandum of the potentially devastating economic effects which could result from the Portuguese Jews' expulsion ${ }^{49}$. Five years earlier, the Spanish government had faced similar problems.

Gedalya also summarizes Samuel Usque's account of the 1506 Lisbon bloodshed ${ }^{50}$, when more than four thousand New Christians were brutally murdered. The riots resulted from the discovery that some conversos had celebrated the Passover Seder that year ${ }^{51}$.

A turning point in the history of the converso community in Portugal was the establishment of the Royal Inquisition in 1531. Like its Spanish counterpart established fifty years earlier, its function was to investigate New Christians suspected of observing Jewish customs ${ }^{52}$. Consequently, many conversos fled Portugal for various points in Europe and the Orient, a fact clearly reflected in Jewish and Portuguese sources. Gedalya, who very briefly records this event ${ }^{53}$, appends some important details to his account. He notes that from the inception of the Portuguese persecutions until 1540,

\footnotetext{
${ }^{48}$ MS. 209r; P. $116 r$.

${ }^{49}$ See N. Slouchz, האנוסים בפורטוגאל, Tel-Aviv 1932, p. 10.

${ }^{50}$ Usque, chap. 29; G. I. Gelbart, A Consolation, pp. 365-369.

${ }^{51}$ This event was also described by Solomon Ibn Verga, שבט יהודה, chap. 60, p. 126. Y. H. Yerushalmi devoted a comprehensive study to this episode. See Y. H. YeruShalmi, The Lisbon Massacre of 1506 and the Royal Image in the Shebet Yehuda, Cincinnati 1976.

${ }^{52}$ See M. Kayserling, Geschichte, pp. 185 ff.; C. Roth, A History of the Marranos, Philadelphia 1947, pp. 69-73; A. Herculano, History of the Origin and Establishment of the Inquisition in Portugal, New York 1972 [reissue of the 1926, translation from the Portuguese, with an introduction by Y. H. Yerushalmi]; Y. H. YerushalmI, «A Jewish Classic", pp. $77 \mathrm{ff}$.

${ }^{53}$ R. Gedalya relied on Usque, chap. 30; G. I. Gelbart, A Consolation, pp. 370374.
} 
more than twenty thousand conversos left Portugal and returned to their original faith, mainly in Muslim countries, namely in the Ottoman empire ${ }^{54}$.

Some maintain that from the beginning of the persecutions ${ }^{55}$ until 5300 [1540], more than twenty thousand conversos left [Portugal] and returned to Judaism in various corners of the world, in Greece and in Turkey ${ }^{56}$.

We have no evidence confirming or contradicting Gedalya's numerical estimate. But, indeed, we do know that many Portuguese conversos did find their way to the Orient. Gedalya also indicates the existence of an important contemporary converso center in Ferrara (northern Italy), where conversos could openly return to their forefathers' faith, even though the town was under Christian hegemony. As Gedalya states:

In that year [1535], Ercole, the Duke of Ferrara, allowed the conversos fleeing Portugal due to persecution by the Inquisition, and who had been inspired by God to return to Judaism to settle in Ferrara, and to perform circumcisions as well. Converso immigration to Ferrara. continued each year, and [a community] exists to this day ${ }^{57}$.

Our knowledge of the converso center in Ferrara and its central figures is unsystematic and random in nature ${ }^{58}$. We have some information on the Mendes-Nasi family, Dona Gracia and her sonin-law Don Joseph Nasi, who transferred their financial activities from Antwerp to Venice and afterwards to Ferrara, where they

\footnotetext{
54 See A. DAvID, "Safed, foyer de retour au Judaïsme de Conversos au XVIe siècle», REJ 146 (1987) 63-83. For bibliographical data on the settlement of conversos in the Ottoman Empire, see ibid., 63-65, nn. 1-8.

55 Namely, the establishment of the Royal Inquisition in 1531.

${ }^{56}$ MS. 210r. In the printed version which was completed approximately twenty years later, Gedalya informs us (fol. 116v) that within fifty years more than thirty thousand coversos fled Portugal.

57 MS. 212r-v.

58 See R. BonfIL, «The History», pp. 219-220, 223; A. DAvID, "The Martyrdom of the Proselyte Joseph Saralvo", Immanuel 20 (1986) 96-100. I. M. HAssán - A. Berenguer AmAdor (eds.), Introducción a la Biblia de Ferrara: Actas del Simposio Internacional sobre la Biblia de Ferrara, Madrid 1994.
} 
openly returned to Judaism ${ }^{59}$, as well as about the Usque family who actively assisted the conversos and ex-conversos arriving in Ferrara. Two of its outstanding members were the ex-converso Samuel Usque, the well-known historian mentioned earlier, and his brother Abraham Usque, who founded a press in Ferrara in order to publish Jewish literary material for the Portuguese ex-conversos ${ }^{60}$. Both families played a prominent role in helping conversos return to Judaism.

\section{CONCLUSION}

In conclusion, it seems that Gedalya cannot be viewed as he was by many scholars, merely as a simplistic eclectic. Although Gedalya was content with commonplace material gathered and selected from a few well-known chronicles in his historiographical treatise, nevertheless he was not simply an undiscriminating copyist. Rather, as we saw, especially in the examples cited from the part of his work concerning the persecution of Iberian Jews, Gedalya attempted to supplement and enrich the bare facts with new information as well as to shed new light based on additional Jewish and non-Jewish sources. To these efforts we must apparently add his numerical estimates, as well as his recording of various factual details. Gedalya's aim was to provide information based upon his understanding of the situation and upon personal observation. It is these aspects that establish his place in sixteenth century Jewish historiography.

\footnotetext{
59 Many studies exist regarding this family. See, for example, A. Galante, Don Joseph Nassi, duc de Naxos, Constantinople 1913; C. Roth, The House of Nasi, Philadelphia 1948; P. Grunebaum-Ballin, Joseph Naci - Duc de Naxos, Paris 1968; B. Ravid, "Money, Love, and Power Politics in Sixteenth Century Venice: The Perpetual Banishment and Subsequent Pardon of Joseph Nasi», Italia Judaica 1 (1983) 159-181; A. DAvID, «New Hebrew Sources on the History of the Mendes-Nasi Family in Italy and Constantinople» [in Hebrew], Kiryat Sefer 64 (1992-1993) pp. 1105-1110.

${ }^{60}$ On Abraham Usque and his press, see C. Roth, «The Marrano Press at Ferrara, 1552-1555", Modern Language Review 38 (1943) 307-317; Y. H. YerushaLmI, "A Jewish Classic», pp. 77-101; R. SEGRE, "Contribución documental a la historia de la imprenta Usque y de su edición de la Biblia", in I. M. Hassán - A. Berenguer AMADOR (eds.), Introducción a la Biblia de Ferrara: Actas, pp. 205-226.
} 


\section{RESUMEN}

Gedalya (1526-1587), considerado por muchos estudiosos como un autor simplistamente ecléctico que seleccionaba un material muy común de crónicas ya conocidas, no era un simple copista, sino que, como se ve especialmente en los ejemplos tomados de la parte de su trabajo sobre la persecución los judíos de la Península Ibérica, Gedalya intenta complementar y enriquecer los meros hechos con nueva información basada en fuentes adicionales judías y no judías. La finalidad de Gedalya era proporcionar información partiendo de su comprensión de las situaciones y de su observación personal. Estos aspectos son determinantes del lugar que se le asigna en la historiografía judía del siglo XVI.

\section{SUMMARY}

Gedalya (1526-1587), considered by many scholars merely as a simplistic eclectic author, content with commonplace material from a few well-known chronicles, was not simply an undiscriminating copyst; rather, as we see especially in the examples cited from the part of his work concerning the persecution of Iberian Jews, Gedalya attempted to supplement and enrich the bare facts with new information based on additional Jewish and non-Jewish sources. Gedalya's aim was to provide information based upon his understanding of the situation and upon personal observation. These aspects determine his place in sixteenth century Jewish historiography. 